UDC 332.33

\title{
REGULATORY AND LEGAL SUPPORT OF ORGANIZATION OF ORGANIC LAND USE AND WAYS OF ITS IMPROVEMENT
}

Y.M. Dorosh, Doctor of Economics Sciences

E-mail:landukrainenaas@gmail.com

A.V. Barvinskyy, $P h D$ in agricultural science

E-mail:barv@ukr.net

Land Management Institute of the

National Academy of Agrarian Sciences of Ukraine

O.S. Dorosh, Doctor of Economics Sciences

E-mail: dorosh_o@nubip.edu.ua

National University of Life and Environmental Sciences

nature management of Ukraine

D.M. Melnyk PhD of Economics Sciences

E-mail: melnykdenys@gmail.com

\section{A.A. Vysidalko}

E-mail: anastasia.visidalko@gmail.com

Land Management Institute of the

National Academy of Agrarian Sciences of Ukraine

Abstract. The article analyses the regulatory and legal support for the organization of organic land use in Ukraine. It is established that the current regulations in the field of organic production are aimed mainly at regulating the technological processes of organic production, the procedure for its certification and the market of organic products. At the same time, the legislators did not pay attention to the issues related to the organization of the territory of agricultural enterprises for the production of organic products in order to meet the requirements of the relevant standards and rules of IFOAM. 
It is proved that for the organization of the territory of organic land use and land tenure it is necessary to develop and implement appropriate land management projects. In view of this, it is necessary to amend the Law of Ukraine "On Land Management", supplementing Article 25 with a new type of land management documentation: land management projects for the organization of organic land use (land tenure), and to enshrine the composition and content of such land management projects.

Key words: normative-legal regulation, organic land use, buffer zone, crop rotation, land management project.

Formulation of the problem. The organization of organic land use in Ukraine is carried out in line with global trends of greening of the agricultural sector, caused by the urgent need to provide the population with quality, safe for human health agricultural products, preservation and reproduction of land resources, maintaining the environment. However, despite the well-founded recommendations of national scientific institutions to optimize excessive anthropogenic pressure on the most important component of agricultural landscapes - soil cover, often economic benefit is the main goal of domestic agricultural producers.

Ignoring the requirements of environmental safety, which is observed in modern traditional agricultural production, leads to significant degradation of soil resources, the spread of water erosion and deflation, reducing the content of organic matter and mineral nutrients in the upper soil layer, environmental pollution by chemicals due to excessive fertilizers, etc. Due to this, the introduction of alternative environmentally friendly methods of agriculture has become urgent, among which organic production occupies a prominent place. Its advantages are due not only to the optimization of the soil-forming process, but also to the formation of sustainable multifunctional agricultural systems that will become the basis for the harmonious development of rural areas in the short and long term.

The problem is that the existing legal framework in the field of organic land use due to certain shortcomings and gaps can not provide a favorable competitive 
environment for the functioning of domestic organic farms, especially due to lack of legal land management mechanism for the formation and balanced development of land use and land tenure. Therefore, at the current stage of development of land relations, solving this problem requires finding ways to improve the regulatory framework for the organization of organic land use in the country, taking into account the requirements of the International Federation of Organic Agricultural Movement (IFOAM), climatic and socio-economic conditions of domestic entities. on earth.

Analysis of recent research and publications. The scientific works of V.I.Artysh [2], N.A.Berlach [3], M.V.Kapshtyka [10], S.M.Romanko [17] and others. At the same time, theoretical-methodological and applied aspects of the organization of organic production are considered in the works of S.S.Antonets [1], V.M.Budziak [4], V.I.Kysil [11], O.G.Tarariko [19], A.G.Tikhonov [20], G.M.Shpak [21] and others, on the basis of which a system of knowledge was formed, which is a scientific basis for the development of organic land use as the main mechanism of greening of agriculture in Ukraine.

However, there are almost no publications on the legal framework for the organization of organic land use, in particular on the spatial distribution of relevant land holdings and land uses, assessment of the suitability of agricultural land for organic production, establishment of buffer zones for separation of organic and inorganic land use, formation of organic crop rotations. adapted to specific naturalclimatic and socio-economic conditions of agricultural producers, etc. Many of these issues are debatable and, therefore, require further research and generalizations. In addition, the imperfect legal framework in this area is a significant obstacle to the intensive development of organic land use at both the national and local levels.

The purpose of the article is to analyze the regulations that provide regulation in the field of organic land use, and justify ways to improve them.

Presenting main material. The set of legislative acts regulating relations in the field of agricultural organic production includes the Laws of Ukraine (LA): 
"On the basic principles and requirements for organic production, circulation and labeling of organic products” of July 10, 2018 №2496-VIII [16], “On Plant Protection” of October 14, 1998 №180-XIV, “On Veterinary Medicine” of June 25, 1992 №2498-XII, “On Aquaculture” of September 18, 2012 №5293-VI, “On Flora” of April 9, 1999 №591-XIV, "On the animal world” of December 13, 2001 №2894-III, etc.

Among other things, these legislative acts define the rights and obligations of organic market participants, requirements for organic production, the content of its certification and the general basis of state regulation of relevant processes. In particular, the main principles of state policy in this area include: "legality compliance with the Constitution and laws of Ukraine, Ukraine's international obligations; parity and equality - ensuring equal opportunities for operators; openness - ensuring free access to information on the development of organic production and circulation of organic products in Ukraine; coordination - the relationship and coherence of long-term strategies, plans and programs for the development of organic production and the market of organic products in Ukraine; sustainable development - the development of organic production and the market for organic products to meet the needs of the current generation, taking into account the interests of future generations; objectivity - the development of all documents that define the state policy in the field of organic production, circulation and labeling of organic products, based on real indicators that can be achieved and evaluated; coherence of economic interests of operators, society and the state; compliance with environmental safety requirements in the field of organic production and / or circulation of organic products; recognition of freedom of economic activity in the field of organic production and / or circulation of organic products; freedom to disseminate information about organic production and circulation of organic products"[16]. The list of principles defined at the legislative level should be supplemented by the "principle of legal protection and responsibility", which prevents interference in economic activities of economic entities, but defines the limits of their responsibility for social, economic and other 
negative consequences of their decisions [9]. According to the authors, it is appropriate to combine such principles as rational use of land use - rational use of land resources, ensuring their preservation and reproduction and science - using the latest scientific developments to increase the efficiency of organic production.

Analysis of current regulations in the field of organic production shows that they are mainly aimed at regulating the technological aspects of organic production through a ban or permit for the use of certain drugs, and does not pay attention to the organization of organic land use and land tenure. At the same time, a prominent place is given to the procedure of certification of organic products, because according to the first part of Article 1 of the Law "On basic principles and requirements for organic production, circulation and labeling of organic products" "organic production is a certified activity related to agricultural production. economic products (including all stages of the technological process, namely primary production (including assembly), preparation, processing, mixing and related procedures, filling, packaging, processing, recovery and other changes in the state of production), carried out with compliance with the requirements of legislation in the field of organic production, circulation and labeling of organic products" [16].

According to the first part of Article 14 of this Law, the general requirements for organic production include "separation in time or space of production and storage of organic products from production and storage of inorganic products and products of the transition period" [16]. However, this normative act does not legally establish specific indicators on the width of the demarcation zone (buffer zone) between organic and inorganic land uses. In general, there are no norms on the organization of organic land use and land tenure with the allocation of crop rotation, based on environmental and economic conditions of organic market operators.

Regulation in the field of organic production is also provided by by-laws issued in accordance with Law №2496-VIII: Resolutions of the Cabinet of Ministers of Ukraine (CMU), which approved the Detailed Rules of Organic 
Production and Circulation of Organic Products and the Certification Procedure for Organic Production.

However, in these acts there are contradictions that can significantly affect the technological process of production of organic crop products, and accordingly its quality. Thus, in accordance with paragraph 5 of the "Procedure (detailed rules) of organic production and circulation of organic products", approved by the Resolution of the Cabinet of Ministers of October 23, 2019 for 70970 "Alternation of crops regarding the cultivation of the next crop, as well as increasing the organic part of the soil and stimulating its biological activity" [14], and according to paragraph 6 "Crop rotation should positively affect soil fertility, maintain a deficient balance of humus and nutrients, reduce weeds, to prevent the spread of pests and plant diseases, as well as to protect the soil from erosion and other degradation processes" [14]. First, it is unclear how to ensure compliance with the requirements of paragraph 5 of the Order in general, and secondly, "increase the organic part of the soil" (paragraph 5) is associated with expanded reproduction of soil fertility, and "deficit-free humus balance" corresponds to a simple reproduction of soil fertility.

According to scientists from the Institute of Agroecology and Nature Management of NAAS, the first step for the introduction of organic agricultural land use in Ukraine was made together with the creation of special raw material zones (GCC), which are defined in the Law "On Baby Food" of September 14, 2006 regions or individual farms that meet the conditions of production of crop and livestock products suitable for the manufacture of baby and diet food" [12]. This is explained by the fact that CVD is often equated to ecologically clean areas of land use of agricultural enterprises, the soil cover of which is suitable for the production of high quality, biologically valuable plant products [18].

Article 8 of the said Law defines the requirements for raw materials from which baby food is made, namely: "raw materials intended for the production of baby food must meet the mandatory safety parameters and minimum quality specifications approved by the central executive body that ensures the formation of 
state policy in the field of health care; raw materials used in the production of baby food may not be produced from genetically modified organisms and / or contain genetically modified organisms" [12]. As evidenced by the above rule, the requirements for raw materials from which baby food is made, and organic products are almost identical.

The general requirements for CVD and the algorithm of the procedure for granting their status are defined by the Resolution of the Cabinet of Ministers of October 3, 2007 №1195. According to paragraph 3 of the Procedure for granting the status of GCC, approved by this Resolution, "special raw material areas must meet the following general requirements: location on land belonging to agricultural lands; normatively justified distance from industrial enterprises and other objects that may pollute the environment; high level of soil fertility; compliance of raw materials with sanitary and hygienic requirements for baby and dietary food, mandatory safety parameters and minimum quality specifications approved by the central executive body for health care; compliance of animal feed with safety and quality requirements; implementation of acts of legislation on veterinary medicine regarding the state of health of animals and sanitary and hygienic conditions of their keeping; availability of documents confirming the registration of the manufacturer raw materials in the relevant state body of veterinary medicine" [15].

In addition, "in a special raw material zone it is prohibited: to carry out the production of livestock products with the use of hormonal and other drugs of artificial origin; to grow and use genetically modified organisms (GMOs) of plant and animal origin" [15].

Undoubtedly, the positive side of this Procedure is the inclusion of the requirement to ensure a high level of soil fertility in the GCC, which will contribute to the production of high quality products with a balanced content of nutrients; ban on the use of hormonal and other drugs of artificial origin and GMOs. The disadvantages include the lack of legally established specific indicators of the distance of the CVD from high environmental hazards and the 
possibility of using the CVD "on special technologies of pesticides and agrochemicals of natural origin" [15].

If we compare the GCC in their status to organic land use, then the methodology for their definition can be extended (of course, with some clarifications) to organic land use. In particular, according to paragraph 6 of the Procedure for granting the status of GCC "to grant the status of a special raw material zone, the raw material producer submits an application in the form approved by the central executive body for agricultural policy to the chairman of the commission with a request to assess, to which are added: materials of agrochemical certification of agricultural lands (agrochemical passports of fields and land plots, issued in the prescribed manner by state design and technological centers for protection of soil fertility and product quality in the Autonomous Republic of Crimea and regions); certificate on the amount of use of pesticides and agrochemicals for the last three years (relevant acts drawn up according to the established form of agricultural accounting, extract from the book of field history); a certificate on the location of agricultural lands in relation to industrial enterprises and facilities that may pollute the environment, as well as roads and railways with heavy traffic, issued by the territorial body of the central executive body for environmental protection; index cadastral map indicating the boundaries of the land plot and cadastral number (numbers), issued by the relevant state and / or other land management organization"[15].

In accordance with paragraph 3.2 of the Procedure for maintaining the agrochemical passport of the field, land, approved by the Order of the Ministry of Agriculture of Ukraine from 11.10.2011. according to N536 "the results of agrochemical certification of agricultural land are used not only in conducting monetary (regulatory and expert) land valuation, determining the amount of land fees, planning measures to restore soil fertility and increase crop yields, adjusting agrotechnology and crop rotation, zoning (zoning) of the territory, monitoring of lands and soils, development of recommendations on rational and ecologically safe use of agrochemicals, but also for determination of raw areas for growing 
agricultural products for production of baby and dietary products and suitability for organic farming" [13].

Assessment of the suitability of agricultural lands of a particular agricultural enterprise for the establishment of GCC is carried out according to the criteria and standards defined in DSTU 7244: 2011: the ecological and toxicological condition of the soil, its ecological stability and soil fertility. According to the values of the indicators of the above criteria, agricultural lands are divided into 3 classes of suitability: "suitable - agricultural lands, the agro-ecological condition of which does not prevent the production of high quality raw materials for the production of baby and diet food; limited suitable - agricultural land, agrochemical indicators of soil fertility and indicators of sanitary and hygienic condition of the soil which allow to obtain high quality raw materials for the production of baby food and dietary food only some crops that are most resistant to toxic substances; unsuitable - agricultural land, where it is impossible to obtain raw materials suitable for the production of baby food and dietary food" [9]. In view of this, agricultural lands that have been assessed as suitable or of limited suitability may be classified as GCC.

The only way to ensure compliance with the requirements for organic land use, given in current regulations in the field of organic production (in particular, spatial separation of organic production from inorganic, formation of soilprotective crop rotations in the system of erosion management, etc.) is the development and implementation of land management projects: on the organization of organic land use, the main feature of which is the introduction of buffer zones for the separation of organic land use from inorganic, sanitary protection zones around farm buildings and structures, the use of which is associated with certain environmental risks (agrochemicals, livestock farms, etc.) crop rotation arrays according to the rules developed by IFOAM [8]. In this regard, there is an underestimation of the ecological content of land management aimed at solving the "root problem of land use - increasing the stability of the landscape, productivity and fertility of land", which provides "unity, integrity, complexity of 
tasks and measures for land use and protection". which is ensured by the implementation of a number of land management functions, “... among which the basic should be forecasting and planning" [5, p. 27; 7, p. 23, 26]. However, such projects are currently not included in the exclusive list of land management documentation provided in Article 25 of the Law on Land Management, and accordingly their composition and content are not approved at the legislative level, which prevents their widespread implementation in agricultural organic production.

Conclusions. Due to a number of shortcomings, the modern legal framework in the field of organic production cannot ensure the sustainable development and harmonious functioning of organic land tenure and land use in Ukraine. Current legislation in this area is aimed primarily at regulating the technological processes of organic production, certification procedures and the market for organic products. At the same time, many questions regarding the organization of the territory of agricultural enterprises for the production of organic products in order to meet the requirements of the relevant standards and rules of IFOAM remain out of the attention of both researchers and legislators.

An effective means of solving problems in the field of organic production in general and organic crop production - in particular is the development and implementation of relevant land management projects, which will ensure the spatial separation of organic and inorganic land use, formation of organic crop rotations, preservation and reproduction of soil quality. crops from the possible negative impact of high environmental hazards, etc. and as a result - obtaining high quality environmentally friendly crop and livestock products. For wide implementation of these land management projects in the practice of organic agricultural production it is necessary to supplement the exclusive list of land management documentation provided in Article 25 of the Law of Ukraine "On Land Management" with a new type of documentation: land management projects for the organization of organic land use (land tenure) equal their composition and content. 


\section{REFERENCES:}

1. Antonets S.S., Antonets A.S., Pysarenko V.M. (2010). Orhanichne zemlerobstvo: z dosvidu PP «Ahroekolohiia» Shyshatskoho raionu Poltavskoi oblasti: Praktychni rekomendatsii. Poltava, Ukraine: RVV PDAA, 200.

2. Artysh V.I. (2010). Udoskonalennia systemy derzhavnoho rehuliuvannia vyrobnytstva orhanichnoi produktsii v Ukraini. Naukovyi visnyk NUBiP Ukrainy. Vyp. 145. Available at : http://www.nbuv.gov.ua/Portal/chem biol/nvnau/2010_145/10avi.pdf

3. Berlach N.A. (2010). Vdoskonalennia spetsialnoi normatyvnopravovoi bazy - priorytetnyi chynnyk rozvytku orhanichnoho silskoho hospodarstva v Ukraini Forum prava, 1, 19-23.

4. Budziak V.M., Budziak O.S. (2012). Ekolohizatsiia zemlekorystuvannia. Naukovyi visnyk Natsionalnoho universytetu bioresursiv i pryrodo-korystuvannia Ukrainy, 4, 34-37.

5. Dorosh Y.M. (2011). Prohnozno-planuvalni funktsii zemleustroiu ta perspektyvy rozvytku terytorii. Zemlevporiadnyi visnyk, 20, 27.

6. Dorosh O.S. (2004). Udoskonalennia upravlinnia zemelnymy resursamy na rehionalnomu rivni [Improving land management at the regional level]. Kyiv, $224 \mathrm{~s}$.

7. Dorosh O.S. (2012). Ekoloho-ekonomichne spriamuvannia terytorialnoho planuvannia silskohospodarskoho zemlekorystuvannia. Zemlevporiadnyi visnyk, 9, $22-27$.

8. Dorosh O.S., Barvinskyi A.V., Kolisnyk H.M., Svyrydova L.A. (2020). Naukovo-metodychni pidkhody do rozrobky eksperymentalnykh proektiv zemleustroiu shchodo orhanizatsii terytorii derzhavnykh naukovykh ustanov ta pidpryiemstv dlia vyrobnytstva orhanichnoi produktsii. Zemleustrii, kadastr i $\begin{array}{llll}\text { monitorynh } & \text { zemel. } & 2-3, & \text { 136-148. }\end{array}$ http://dx.doi.org/10.31548/zemleustriy2020.02.14 
9. DSTU 7244:2011 (2011). Yakist gruntu. Spetsialni syrovynni zony. Zahalni vymohy Kyiv, Ukrainy, 16 s. Available at : http://online. budstandart.com/ua/catalog/doc-page.html?id_doc=60260

10. Kapshtyk M.V. (2012). Normatyvno-pravove zabezpechennia orhanichnoho vyrobnytstva v Ukraini: problemy ta perspektyvy. Ahroekolohichnyi zhurnal, 1, 25-31.

11. Kysil V.I. (2005). Ahrokhimichni aspekty ekolohizatsii zemlerobstva. UAAN: NNTs «In-t hruntoznavstva ta ahrokhimii im. O.N. Sokolovskoho». Kharkiv, Ukrainy: 13 typohrafiia, $167 \mathrm{~s}$.

12. Zakon Ukrainy «Pro dytiache kharchuvannia» vid 14 veresnia $2006 \mathrm{r}$. №142-V. Available at : https://zakon.rada.gov.ua/laws/show/142-16\#top

13. Nakaz Ministerstva ahrarnoi polityky ta prodovolstva Ukrainy «Pro zatverdzhennia Poriadku vedennia ahrokhimichnoho pasporta polia, zemelnoi dilianky» vid 11.10.2011r. za N536. Available at : https://zakon.rada.gov.ua/laws/show/ z1517-11\#Text

14. Postanova Kabinetu Ministriv Ukrainy Pro zatverdzhennia Poriadku (detalnykh pravyl) orhanichnoho vyrobnytstva ta obihu orhanichnoi produktsii vid 23 zhovtnia 2019 r. №970. Available at : https://zakon.rada.gov.ua/laws/show/ 970-2019-\%D0\%BF\#n636

15. Postanova Kabinetu Ministriv Ukrainy «Pro zatverdzhennia Poriadku nadannia statusu spetsialnoi zony $\mathrm{z}$ vyrobnytstva syrovyny, shcho vykorystovuietsia dlia vyhotovlennia produktiv dytiachoho ta diietychnoho kharchuvannia» vid 3 zhovtnia 2007 r. N1195. Available at : https://zakon.rada.gov.ua/laws/show/1195-2007-\%D0\%BF\#Text

16. Zakon Ukrainy Pro osnovni pryntsypy ta vymohy do orhanichnoho vyrobnytstva, obihu ta markuvannia orhanichnoi produktsii vid 10 lypnia 2018 roku № 2496-VIII Available at : http://zakon.rada.gov.ua/laws/show/2496-19

17. Romanko S. (2007). Osoblyvosti ekonomiko-pravovoho mekhanizmu zabezpechennia ekolohichnoi bezpeky silskohospodarskoi produktsii. Pravo Ukrainy, 6, 85-88 
18. Sozinov O.O., Kozlov M.V. (1998). Otsinka prydatnosti silskohospodarskykh zemel Ukrainy dlia stvorennia ekolohichno chystykh syrovynnykh zon i hospodarstv po vyrobnytstvu produktiv dytiachoho i diietychnoho kharchuvannia: Metodychni rekomendatsii, Kyiv, Ukrainy: 58 s.

19. Tarariko O.H., Ilienko T.V. (2013). Formuvannia ekolohichno stiikykh landshaftiv v umovakh zmin klimatu. Ahroekolohichnyi zhurnal, 4, 13-20.

20. Tykhonov A.H., Hrebeniuk N.V., Tykhonenko O.V., Fedenko V.P. (2003). Naukovi zasady staloho rozvytku zemlekorystuvannia: indykatsiia ekolohichnoho stanu. Zemleustrii i kadastr, 3, 15-20.

21. Shpak H.M. (2012). Orhanizatsiino-ekonomichnyi mekhanizm upravlinnia orhanichnym zemlerobstvom v Ukraini. Naukovyi visnyk NLTU Ukrainy: Zbirnyk naukovo-tekhnichnykh prats, Lviv, Ukrainy, 22(9), 85-92.

ДОРОШ Й.М., БАРВИНСКИЙ А.В., ДОРОШ О.С., МЕЛЬНИК Д.Н., ВИСИДАЛКО А.А.

НОРМАТИВНО-ПРАВОВОЕ ОБЕСПЕЧЕНИЕ ОРГАНИЗАЦИИ ОРГАНИЧЕСКОГО ЗЕМЛЕПОЛЬЗОВАНИЯ И ПУТИ ЕГО СОВЕРШЕНСТВОВАНИЯ

Аннотация. В статье проанализированы нормативно-правовое обеспечение организации органического землепользования в Украине. Установлено, что ныне действующие нормативно-правовые акты в области органического производства направлены в основном на регулирование технологических прочессов производства органической продукиии, порядка его сертификации и рынка органической продукции. В то же время, без внимания законодателей остались вопросы, касающиеся организации территории аграрных предприятий для производства органической продукиии с изелью обеспечения требований соответствующих стандартов и правил IFOAM.

Доказано, что для организачии территории органических землепользования и землевладения необходима разработка и реализация 
соответствующих проектов землеустройства. Несмотря на это, нужно ввести изменения в Закон Украины «О землеустройстве», дополнив статью 25 новым видом документации по землеустройству: проектами землеустройства по организациии территории органического землепользования (землевладения), и закрепить законодательно состав и содержание таких проектов землеустройства.

Ключевые слова: нормативно-правовое регулирование, органическое землепользования, буферная зона, севооборот, проект землеустройства.

ДОРОШ Й.М., БАРВІНСЬКИЙ А.В., ДОРОШ О.С., МЕЛЬНИК Д.М., ВИСІДАЛКО А.А.

НОРМАТИВНО-ПРАВОВЕ ЗАБЕЗПЕЧЕННЯ ОРГАНІЗАЦІЇ ОРГАНІЧНОГО ЗЕМЛЕКОРИСТУВАННЯ ТА ШЛЯХИ ЙОГО УДОСКОНАЛЕННЯ

Анотація. У статті проаналізовано нормативно-правове забезпечення організачїі органічного землекористування в Украӥні. Встановлено, щуо нині діючі нормативно-правові акти в галузі органічного виробництва спрямовані в основному на регулювання технологічних прочесів виробництва органічної продукиї, порядку його сертифікації та ринку органічної продукції. Водночас, поза увагою законодавців заличились питання, щуо стосуються організації територї аграрних підприємств для виробництвва органічної продукції з метою забезпечення вимог відповідних стандартів та правил IFОАМ.

Доведено, щзо для організащзї території органічних землекористувань mа землеволодінь необхідна розробка та реалізація відповідних проектів землеустрою. Зважаючи на цее, потрібно ввести зміни до Закону України «Про землеустрій», доповнивии Статтю 25 новим видом документації із землеустрою: проектами землеустрою щ⿻одо організації території органічного землекористування (землеволодіння), $і$ закріпити законодавчо склад та зміст таких проектів землеустрою. 
Ключові слова: нормативно-правове регулювання, органічне землекористування, буферна зона, сівозміна, проект землеустрою. 